\title{
DEMATEL-ANP Risk Assessment in Oil and Gas Construction Projects
}

\author{
Gholamreza Dehdasht ${ }^{1}$, Rosli Mohamad Zin ${ }^{1}$, M. Salim Ferwati ${ }^{2}$ (D), \\ Mu'azu Mohammed Abdullahi ${ }^{3}$, Ali Keyvanfar 4,5,6,7,* (D) and Ronald McCaffer ${ }^{8}$ \\ 1 Department of Structure and Materials, Faculty of Civil Engineering, Universiti Teknologi Malaysia, \\ Skudai 81310, Malaysia; dehdasht1387@gmail.com (G.D.); roslizin@utm.my (R.M.Z.) \\ 2 Department of Architecture and Urban Planning, College of Engineering, Qatar University, Doha 2713, \\ Qatar; sferwati@qu.edu.qa \\ 3 Civil Engineering Department, Jubail University College, Royal Commission of Jubail and Yanbu, \\ Jubail 31961, Saudi Arabia; mailto:muazum@ucj.edu.sa \\ 4 Faculty of Built Environment, Universiti Teknologi Malaysia, Skudai 81310, Malaysia \\ 5 MIT-UTM MSCP Program, Institute Sultan Iskandar, Universiti Teknologi Malaysia, Skudai 81310, Malaysia \\ 6 Facultad de Arquitectura y Urbanismo, Universidad Tecnológica Equinoccial, \\ Calle Rumipamba s/n y Bourgeois, Quito 170508, Ecuador \\ 7 School of Architecture and Urban Planning, Iran University of Science and Technology, Tehran 11369, Iran \\ 8 School of Architecture, Building and Civil Engineering, Loughborough University, \\ Loughborough LE11 3TU, UK; r.mccaffer@lboro.ac.uk \\ * Correspondence: akeyvanfar@utm.my; Tel.: +60-177033482
}

Received: 13 June 2017; Accepted: 31 July 2017; Published: 11 August 2017

\begin{abstract}
Oil and gas construction projects are complex and risky because of their dynamic environment. Furthermore, rising global energy demand has increased the need for trustworthy risk assessment models for such projects that can provide adequate and precise policy planning. Traditional risk assessments in oil and gas construction projects do not consider the interrelationships of factors in the best-fit models. The Decision Making Trial and Evaluation Laboratory (DEMATEL) and Analytic Network Processes (ANP), called the DEMATEL-ANP approach, have been applied to other research disciplines to address this shortcoming. This method is able to construct a structural relationship among the different influence factors to visualize complex correlations. Thus, the purpose of this study is to showcase the DEMTAL-ANP risk assessment model to assess the overall risk factors of OGC projects. This study thus identifies the crucial risk criteria of such projects. Data were collected in 2016 through interviews with experts active in OGC projects in Iran. DEMATEL in this situation is used to determine the interdependencies' relative strengths among the risks. The ANP method is applied to assess the relative importance of the risk factors and to determine the best strategy for implementation of a risk management program. The results presented in this study are a novel adaptation of the risk assessment methodology to OGC projects that determines the important risk factors that directly affect the project success, which in turn helps in formulation of policies for ensuring reliable energy supply planning.
\end{abstract}

Keywords: risk assessment; construction project; oil and gas; DEMATE; ANP

\section{Introduction}

Energy demand is rising, and it is anticipated that worldwide investment in energy-related projects will reach $\$ 38$ trillion through 2035 [1,2]. In the discussions of sustainable development, energy is one of the key factors that must be considered [3-5]. OGC projects are composed of high levels of risk because of intensive investment, numerous stockholders, complex technology, and unique 
nature [6,7]. These risks can be economic, political, social, and technical in nature, as well as related to the natural environment and natural disasters $[8,9]$. Recognizing the risk related to energy is not only a construction market need, but also it is important to the upstream as well as downstream oil and gas industry sub-sectors [10]. Construction projects play a key role in the sustainable oil and gas supply chain and processing [11,12]. Due to this importance, governments of developing countries are under pressure to ensure that projects will be finished on time with least amount of risk and uncertainty [13]. A proper risk management strategy leads to lower costs and increases competitiveness in the energy market [14]. Therefore, it's necessary to identify and assess the major risks faced by OGC projects, in order to help companies that plan or work in such projects develop plans to ensure sustainable energy supply chains. Furthermore, recognizing, highlighting and analyzing the important risk factors associated with OGC companies can assist in proper planning, successful implementation of risk management and appropriate responses to eliminate, transfer or control the corresponding risks.

The construction industry is widely associated with a high degree of risk because of its nature, process, activities, technological complexity, organization and environment $[15,16]$. ISO 31000 has introduced risk as "an effect of uncertainty on objectives" and risk factor has been defined as a fact or situation that increases the possibility of risk, according to Cambridge Dictionary. Factors that increase this risk are a growing number of stakeholders, long duration of a project and interface with a reaction between external and internal environment [17]. Engagement with various participants, such as designers, owners, suppliers, contractors and subcontractors are an additional reason for a high volume of fundamental risks $[18,19]$. In the body of knowledge of project risk management, there are a number of orderly and official methods for identifying, assessing, classifying, responding and managing risks during the life cycle of a project [20,21]. It is a dynamic process that tends to decrease the probability and effect of negative events and promote the probability and effect of positive events [22] to attain an optimal grade of risk elimination, control, and mitigation [21]. Project risk may have a negative or positive impact on at least one of the project objectives, for example, cost, time, quality, etc. [19,23]. All construction projects contain risk that can be minimized, managed, transferred, accepted or ignored $[24,25]$. It is impossible to remove all project risks. Therefore, successful projects are those that identify risks at an early stage and efficiently assess and manage them $[15,26]$. On the other hand, a lack of adequate attention and assessment of risk in a construction project is the cause of cost overruns, poor performance, and delay [23,27]. Unfortunately, construction projects are not as advanced at analyzing and assessing risks compared with many other industries [28,29]. Lack of a risk management methodology during OGC projects not only can lead to delays and cost overruns but also can be critical for pricing energy policies [13]. Thus, there is a need for identifying the most important group risks and related risk factors because of the effect on construction decision making. Therefore, to increase the chance of success and decrease possible risk in a construction project, the major group risks and uncertain factors should be recognized, classified, assessed and monitored.

Recently, several studies have applied Multi-Criteria Decision Making (MCDM) techniques, such as TOPSIS, AHP, ANP, and DEA, for risk assessment of construction projects [19,30-32]. MCDM has been applied in oil and gas upstream and downstream industry as well $[3,33]$. These techniques are very useful, especially for dealing with complex problems, complex systems, unclear variables and limited information $[23,34]$.

Traditional risk assessment in OGC projects has not considered the interrelationship of factors in the best-fit models [7,35,36]. The Decision Making Trial and Evaluation Laboratory (DEMATEL) and Analytic Network Processes (ANP), called the DEMATEL-ANP approach, have been applied to other research disciplines to address this shortcoming [37,38]. According to Fazli et al. [37], the combination of DEMATEL and ANP is the best risk mitigation strategy due to the fact that DEMATEL is able to visualize the complex interrelationships among criteria. ANP assesses the dependencies and feedbacks among factors to select the relative weights of the risk factors. DEMATEL-ANP is thus an effective method that helps managers to select the best strategies to respond to the overall risks effectively. 
The objective of this paper is to determine the key risk groups and risk factors and propose a risk assessment framework to evaluate the overall risks in OGC projects. To find an influence strategy to respond to potential risks within OGC projects, it is necessary to analyze interdependencies among risks and identify the most important that influence risks. The integrated hybrid methodology of the DEMATEL and ANP approaches was employed to determine the interdependency of the risks and the importance of each risk factor. The final model is also simulating the impact of different possible risks in organization and their performance in OGC projects.

DEMATEL is a complete method for constructing a structural model to solve the complex interrelationships by describing cause and effect groups or factors. The DEMATEL technique is according to diagraphs which can divide influence criteria into cause and effect groups. Based on the results obtained from DEMATEL method, the ANP model can be constructed. In fact, DEMATEL solves the problem of unrealistic interdependencies of ANP that were determined in the first step of the said method. ANP method has been made to manage uncertain human judgments [39]. The DEMATEL-ANP approach has been employed in order to promote the abilities of the ANP method for managing inconsistent and uncertain judgments of decision makers in risk group prioritization and relative risk factor weights within OGC projects.

The rest of this paper is organized as the following. In Section 2, related literature gap and the contribution of this study towards risk assessment in OGC projects are presented. Subsequently, Section 3 describes the risk management process including the most important risk groups and risk factors as well as the fuzzy risk assessment process. In addition, both DEMATEL and ANP are introduced. Next, in Section 4, a hierarchical structure of project risk factors for OGC projects is proposed. The said section also entails DEMATEL-ANP calculation outcomes and the results of this research. Finally, Section 6 concludes the study.

\section{Problem Statement and Our Contributions}

This paper investigates the significant risk groups and associated risk factors in order to propose a risk assessment methodology for OGC projects. The questions that have been investigated in this research are: (1) What are the current practices of risk management in construction projects? (2) What are the important risk groups and risk factors that influence the implementation of risk management in OGC projects? (3) What would be the result of applying the DEMATEL-ANP method to construction risk assessment of oil and gas projects?

We can divide the significance of this study into two sections: First, construction risk related to oil and gas companies has not been thoroughly studied. According to Haghnevis and Sajedi [40], despite various studies and proposed methodologies and models for managing risk, a specific methodology or model with concentrations on a single industry and its unique applications still had not been developed The same observation also is well understood by research reported by Gilbert et al. [41]. Also, previous studies on risk management within OGC projects, concentrated more on risk identification rather than proposing new risk assessment methodologies $[7,35]$. In this regard, there is a lack of development of a methodology for the particular assessment of risks for OGC projects. Furthermore, based on Kuo and $\mathrm{Lu}$ [32], it is necessary to study more creative risk assessment results further. Therefore, the purpose of this study is to propose a novel methodology for risk assessment that is suitable for OGC projects.

Secondly, this paper investigates the significant level of interdependency between critical risk factors necessary for developing an implementation plan for risk management in OGC projects. DEMATEL-ANP has been applied to assess and predict the level of importance for determined risk factors to develop a risk management implementation plan in OGC projects. In this respect, DEMATEL is used to construct the interrelations among the risk factors in the integrated model. This method tests the relative strength between risk factors. Also, the ANP technique, which is used for defining the relative importance of risk factors, is presented. This method is used for weighting and prioritizing critical risk factors in OGC projects. 


\section{Risk Management}

Risk management is one of the most important parts of decision making because risk has serious effects on quality, productivity, performance and budget [42,43]. Construction projects are exposed to high levels of risk and uncertainty because of their dynamic and complex nature [44,45]. Project success is threatened by risks, and ignoring risk has been shown to be a source of time and cost overruns in construction projects [42]. Risk management is a significant part of project management because it involves predicting the occurrence of events that have a negative effect on the project objective and defining proper actions to minimize the impact of these events [46,47].

Several studies have defined risk management, but the conclusion of these studies is mostly to minimize the risk impact and maximize the opportunities [48-50]. Risk management is a policy that can be described as a plan or principle to make decisions to obtain the desired consequences $[8,51]$. The ISO 31000:2009 standard recommends a risk management framework that uses policies, practices, and procedures throughout the organization. Risk management is a method that functions to identify, classify and quantify all risks related to a project or business so that an informed decision can be made for managing the risks [15]. Risk management is an effective method that not only can help identify different types of risks but also assist in managing these risks in the construction project life cycle $[19,21]$.

It is proven that risk management is necessary for successful projects, and the whole method is employed in various sectors of construction projects to assure the quality of the product in these areas [5,32]. There is a strong connection between the level of project success and focus on risk management [52]. Hence, implementation of risk management has been identified as critical for construction projects to increase their performance and ensure achievement of project objectives [30,53].

The success of risk management requires a wide assessment of risk management processes [32]. In the said field, numerous studies that have suggested various processes for risk management. A formal process of risk management can be divided into several categories, i.e., risk identification and classification, risk assessment, and risk response [54-56]. PMI [57] classified risk management process into six stages, namely (1) risk management planning; (2) risk identification; (3) qualitative risk analysis; (4) quantitative risk analysis; (5) risk response planning; and (6) risk monitoring and control. On the other hand, Althaus et al. [58] categorized six main steps, which included (1) identification of key issues, which could be problems in the future; (2) generating creative analysis; (3) presentation of new methods, which are similar to developing a policy instrument, coordination and consultancy; (4) decision making; (5) operation; and (6) evaluation of policy efficiency.

Consequently, risk management can be summarized as a group of processes that involve recognizing, assessing and ranking risks by managerial resource, monitoring and controlling with organized and economic effort, which would subsequently help to reduce the impact of undesired events that could affect the success of a project [59]. In addition, an effective risk management process requires a project manager to be involved in certain tasks and responsibilities such as promoting confidence to deliver project objectives, providing a series of favorable alternative actions, developing chance of success, reducing undesired events and uncertainties, improving actual estimating, and reducing rework through promoting team awareness about risk [60].

This section is focused on several issues. Firstly, it reports the classification and identification of the most important group of risks as well as risk factors in an OGC project. Secondly, related works for risk management are discussed. Thirdly, the concepts of Analytical Network Process (ANP) approach as well as Decision Making Trial and Evaluation Laboratory (DEMATEL) are introduced. Figure 1 presents an overview of a risk assessment process, which is also a hybrid proposed model using both ANP and DEMATEL. As shown in Figure 1, the model consists of three main steps, which include risk identification and classification, risk assessment based on both ANP and DEMATEL, and determining the most important group of risks and risk factors. 


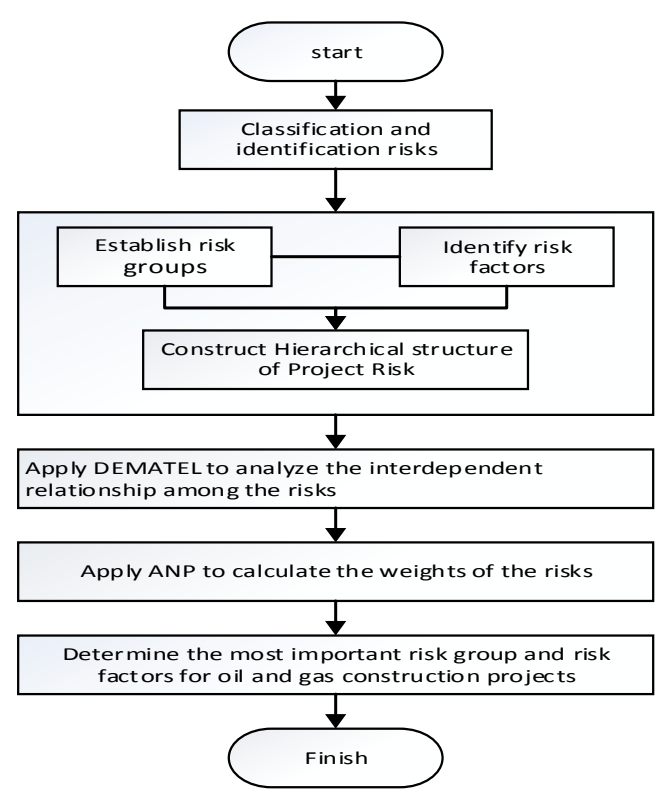

Figure 1. DEMATEL-ANP risk assessment framework.

\subsection{Classification and Identification of Risks}

Risk identification means the method of formulating those risks that may impact project objectives and recording their characteristics [34]. PMBok [61] has defined risk classification as a structure that ensures the effectiveness and quality of the risk identification process into a reliable level. Risk classification and identification is a significant part of risk management because several risks occur in construction projects [62]. The goal of risk identification is to prepare a list of probable risks that should be managed during a project [57]. The risk factors that are present or anticipated should be identified both for their likelihood and impact on project objectives [63]. Risk identification and classification enables the user to enhance the transparency of the analysis $[64,65]$. The lack of identification and classification of risks according to their sources, determination of the possibility of an occurrence and the effect on construction objectives are the main problems of implementing risk management and risk analysis $[45,66]$. It is necessary for construction projects to identify and deal with uncertain risks (some risks are not uncertain, as they can be easily identified before starting a project, for instance, weather conditions). Evaluating their impact on the project objectives helps with planning and managing each potential source of risk [67]. It is impossible to identify all risks in a project [15]. Identification of all risks is time consuming and not productive; therefore, it is important to highlight the most critical risks in construction projects [62].

Construction risks can be classified and identified using different techniques and methods. Several researchers classify risk according to the source and origin of the risk $[15,19,49,68,69]$ or type of risk [70]. In addition, some studies have categorized risk into internal and external groups based on the source of the risk $[62,71,72]$. The difference between internal and external risk is that internal risks are risks that are under the control of the project management team, while external risks are outside the control of the team [73]. Brainstorming, interviews, checklists, benchmarking, questionnaires, Delphi technique, experts' evaluation, and past experience are the most frequent methods used for qualitative risk factor identification in management studies [46,66,74,75]. According to PMI [57], the best method is the one that the project team is most familiar with and most obtained from the project objectives.

Risk identification and classification has been performed in many fundamental studies for construction projects. The outcome of these studies is the classification of numerous risks that impact construction project objectives. Flanagan and Norman [55], and Perry and Hayes [76] classified eight major risks: design, material, planning, weather, subcontractors' manpower, subcontractor 
co-ordination, skill and techniques and poor workmanship. Abdou [77] grouped risks into three subclasses, which are financial, time and design. In a study by Kalayjian [78] about hidden risk frequently encountered in third world construction projects, he introduced four groups of risks that are common in global construction projects: political, financial, weather and design. Tah and Carr [79] divided project risk into internal and external risks using the hierarchical risk breakdown structure (HRBS). Chapman [49] recognized and categorized 58 risks into four groups: project, environment, industry and client. Shen et al. [80] presented 58 risk factors of construction joint ventures in China and classified them into six main groups based on the nature of the risk: legal, policy and political, legal, financial, management and technical. Kartam and Kartam [70] proposed 26 types of risks associated with construction companies in Kuwait. Lam et al. [81] presented 16 risk factors related to construction projects in terms of contractor capability, contractual and legal, political and societal, economic and physical. Zou et al. [15] introduced 85 risk factors for construction in China that were prioritized according to their effects on distinctive project objectives in terms of time, quality, environment, cost and safety. At the same time, Tang et al. [82] in their research for the construction industry in China presented 32 risk factors in five groups: quality, design, safety, financial and facility. Karim et al. [83], in their research about contractor's perceptions of significant risks in construction projects in Malaysia, classified 25 risks in five categories such as construction, political, design, financial and environment. Tadayon et al. [84] found 11 types of risks for construction projects in Iran: financial, construction, product, political, environment, technological, geographical, geotechnical, communication, legal and social.

In a recent study, Kuo and $\mathrm{Lu}$ [32] investigated the relative impact of 20 risk factors on the performance of metropolitan construction projects. These risks were divided into five categories: design, construction management, social and economy, safety and natural hazard. Taylan et al. [19] assessed a construction project in Saudi Arabia and its overall risk for an uncertain and incomplete situation. They evaluated 30 risk factors and classified them into five main categories: cost, time, quality, environment sustainability and safety. Sixteen risk factors were introduced and recognized as critical risk factors. El et al. [85] evaluated the risk factors that affect time and cost contingency in construction projects in Egypt. They divided 70 risk factors into four criteria and thirteen sub criteria. The first criterion is the site condition, which has three sub criteria, which are environmental, sub-surface and site location. The second criterion is project parties, which is divided into labor, equipment and material. The third and fourth criteria are project parties and project features, respectively, which have the sub criteria of owner, engineering design, contractor, project management, financial, political and schedule. Dziadosz and Rejment [66] presented eight risk factors in the three groups of time, budget and design to compare three different methods of risk analysis in construction projects. Baghdadi and Kishk [72] classified 54 risk factors for an airport construction project into three levels: internal, external and force majeure.

Risk management related to OGC projects has not been thoroughly studied. There are just a few studies that have focused on risk management in this sector of construction projects. Thuyet et al. [7] assessed 59 major risk factors related to OGC projects in Vietnam. Ten of these risks factors are identified as the most critical factors. Mubin and Mubin [86] identified 40 risk factors for pipeline construction projects in Pakistan and classified them into eight groups: political, economic, organization, investment, technological, security, natural disaster and ecological risk. In other research by Mubin and Mannan [36], they investigated the risk factors related to engineering, procurement and construction (EPC) contracts for oil and gas projects. They identified 168 risk factors and classified them into seven groups: financial, human, quality, procurement and contractual, project management, proposal and engineering. El-Shehaby et al. [35] evaluated the risk factors related to construction of off-shore oil and gas projects. Fifty-nine risk factors were identified in this research and the top nine risks were recognized as critical risks. Table 1 presents a taxonomy of classification and identification of risk in construction used in this study. 
Table 1. Taxonomy of classification and identification of risk in construction.

\begin{tabular}{|c|c|c|c|c|c|}
\hline Project Type & Risk Class & fication & Author & $\begin{array}{c}\text { Number of Risk } \\
\text { Factors }\end{array}$ & $\begin{array}{c}\text { Risk Factor Identification } \\
\text { Techniques }\end{array}$ \\
\hline Construction Joint Venture & $\begin{array}{l}\text { 1. Legal } \\
\text { 2. Political } \\
\text { 3. Management }\end{array}$ & $\begin{array}{l}\text { 4. Financial } \\
\text { 5. Technical } \\
\text { 6. Market }\end{array}$ & Shen et al. [80] & 58 risks & $\begin{array}{l}\text { Past experience } \\
\text { Interview } \\
\text { Questionnaire survey }\end{array}$ \\
\hline Construction Design Management & $\begin{array}{l}\text { 1. Environment } \\
\text { 2. Industry }\end{array}$ & $\begin{array}{l}\text { 3. Project } \\
\text { 4. Client }\end{array}$ & Chapman [49] & 58 risks & $\begin{array}{l}\text { Interview } \\
\text { Brain storming } \\
\text { Delphi }\end{array}$ \\
\hline Third World Construction Project & $\begin{array}{l}\text { 1. Political } \\
\text { 2. Financial }\end{array}$ & $\begin{array}{l}\text { 3. Weather } \\
\text { 4. Design }\end{array}$ & Kalayjian [78] & Not specified & Interview \\
\hline General Construction Project & $\begin{array}{l}\text { 1. Economic related } \\
\text { 2. Political-related } \\
\text { 3. Design Related } \\
\text { 4. Level of cooperation } \\
\text { 5. Construction related } \\
\text { 6. Estimator related } \\
\text { 7. Fraudulent practices related }\end{array}$ & & Baloi and Price [68] & 36 risks & Literature review \\
\hline General Construction Project & $\begin{array}{l}\text { 1. Contractor capability } \\
\text { 2. Contractual and legal } \\
\text { 3. Economic } \\
\text { 4. Physical } \\
\text { 5. Political and societal }\end{array}$ & & Lam et al. [81] & 16 risks & $\begin{array}{l}\text { Literature review } \\
\text { Consulting experts } \\
\text { Interview } \\
\text { Questionnaire }\end{array}$ \\
\hline General Construction Project & $\begin{array}{l}\text { 1. Time } \\
\text { 2. Cost } \\
\text { 3. Quality }\end{array}$ & $\begin{array}{l}\text { 4. Safety } \\
\text { 5. Environment }\end{array}$ & Zou et al. [15] & 85 risks & $\begin{array}{l}\text { Literature review } \\
\text { Consulting experts } \\
\text { Interview } \\
\text { Questionnaire }\end{array}$ \\
\hline Metropolitan Construction Project & $\begin{array}{l}\text { 1. Design } \\
\text { 2. Construction management } \\
\text { 3. Social and economy } \\
\text { 4. Safety } \\
\text { 5. Natural hazard }\end{array}$ & & Kuo and $\mathrm{Lu}[32]$ & 20 risks & $\begin{array}{l}\text { Literature review } \\
\text { Consulting experts } \\
\text { Interview }\end{array}$ \\
\hline General Construction Project & $\begin{array}{l}\text { 1. Cost } \\
\text { 2. Time } \\
\text { 3.Quality }\end{array}$ & $\begin{array}{l}\text { 4. Environment and } \\
\text { Sustainability } \\
\text { 5. and Safety }\end{array}$ & Taylan et al. [19] & 30 risks & $\begin{array}{l}\text { Consultant experts } \\
\text { Interview } \\
\text { Questionnaire }\end{array}$ \\
\hline
\end{tabular}


Table 1. Cont.

\begin{tabular}{|c|c|c|c|c|c|}
\hline Project Type & & fication & Author & $\begin{array}{c}\text { Number of Risk } \\
\text { Factors }\end{array}$ & $\begin{array}{c}\text { Risk Factor Identification } \\
\text { Techniques }\end{array}$ \\
\hline General Construction Project & $\begin{array}{l}\text { 1. Socio-cultural } \\
\text { 2. Economic } \\
\text { 3. Politic }\end{array}$ & $\begin{array}{l}\text { 4. Industry } \\
\text { 5. Project }\end{array}$ & Aydogan and Koksal [87] & 19 risks & $\begin{array}{l}\text { Literature review } \\
\text { Consulting experts } \\
\text { Interview } \\
\text { Questionnaire }\end{array}$ \\
\hline General Construction Project & $\begin{array}{l}\text { 1. Project Features } \\
\text { 2. Project Parties }\end{array}$ & $\begin{array}{l}\text { 3. Site Condition } \\
\text { 4. Resource }\end{array}$ & El et al. [85] & 70 risks & $\begin{array}{l}\text { Literature review } \\
\text { Consulting experts } \\
\text { Questionnaire }\end{array}$ \\
\hline General Construction Project & $\begin{array}{l}\text { 1. Construction, } \\
\text { 2. Political, } \\
\text { 3. Design, }\end{array}$ & $\begin{array}{l}\text { 4. Financial } \\
\text { 5. Environment }\end{array}$ & Karim et al. [83] & 25 risks & $\begin{array}{l}\text { Literature review } \\
\text { questioner }\end{array}$ \\
\hline OGC Project & Not specified & & Thuyet et al. [7] & 59 risks & $\begin{array}{l}\text { Checklist } \\
\text { Brainstorming } \\
\text { Literature review } \\
\text { Consulting experts }\end{array}$ \\
\hline Gas Pipeline Construction Project & $\begin{array}{l}\text { 1. Political, } \\
\text { 2. Economic, } \\
\text { 3. Organization, } \\
\text { 4. Investment, }\end{array}$ & $\begin{array}{l}\text { 5. Technological, } \\
\text { 6. Security, } \\
\text { 7. Natural Disaster, } \\
\text { 8. Ecological }\end{array}$ & Mubin and Mubin [86] & 40 risks & $\begin{array}{l}\text { Information collection } \\
\text { Documentation review } \\
\text { Assumption analysis } \\
\text { Checklist analysis } \\
\text { Diagramming techniques }\end{array}$ \\
\hline OGC Project & Not specified & & El-Shehaby et al. [35] & 59 risks & $\begin{array}{l}\text { Documentation reviews } \\
\text { Information gathering } \\
\text { Checklist analysis } \\
\text { Assumptions analysis } \\
\text { Diagramming techniques } \\
\text { Risk Register }\end{array}$ \\
\hline
\end{tabular}




\subsection{Risk Assessment Related Work}

Risk assessment is defined as the "procedure of prioritizing risks for further analysis by assessing and combining, generally, their probability of occurrence and impact" [34]. Risk assessment and analysis are significant parts of the risk management procedure. There is a direct connection between successful risk management and effective risk assessment because the assessment results must be employed in the risk management plan [68]. Risk assessment is a technique for recognizing the sources of risk, identifying probable risk factors and computing the potential impact of risk factors on project success [88,89]. Therefore, employing effective risk assessment techniques in managing potential risks associated with construction variables is very important for the successful delivery of the project objectives [15].

Of late, many risk management techniques have been established based on linguistic assessments, which is contrary to numerical values. The fuzzy sets theory [90] is appropriate for dealing with data, which are imprecise and have linguistic terms such as uncertainty, high risk, or serious impact [30]. As argued by Nieto-Morote and Ruz-Vila [34], the said expressions may not present any meaning or context, but the fuzzy sets theory is able to put meaning into them when they are defined by mathematical logs.

Several studies used Multi-Criteria Decision Making (MCDM) techniques such as TOPSIS, AHP, and ANP for risk management assessments. Carr and Tah [91] used a fuzzy approach in a construction project to identify the relationship between the risk source and the effects on the project performance measures. The implementation of fuzzy logic helped the risk management by using an expressive linguistic variable to describe the risk and its consequence. Also, a prototype risk management model was developed using fuzzy logic to support the risk management framework that was presented by them. The results showed that risk management improved the understanding of those involved in the process. Furthermore, risk handling and project performance were improved. Zeng et al. [30] presented a new methodology using fuzzy AHP for risk analysis in construction projects to deal with associated risks in complicated situations. In addition, an analytical hierarchy process was modified to prioritize and structure the driving risk factors. The results demonstrated that the fuzzy technique is a reasonable application for efficiently and effectively assessing risk in construction projects. Dikmen and Birgonul [92] proposed a methodology for rating cost overrun risks using a fuzzy risk assessment for international construction projects. Their suggested methodology applied a fuzzy risk rating method with an effective diagramming process for risk identification. The effective diagram easily modeled the influence risk factors and interactions among these risk factors. Nieto-Morote and Ruz-Vila [34] proposed a methodology for risk management in construction projects based on fuzzy set theory and the AHP approach to model a large number of risks. Additionally, they developed a hierarchical weighting method to assess the weight of risks using pairwise comparisons for the sake of handling problems with a large number of risks in the methodology. Kuo and Lu [32] assessed risks for a metropolitan construction project by employing the Fuzzy Multiple Criteria Decision Making (FMCDM) approach. They employed Consistent Fuzzy Preference Relations (CFPR) to investigate and measure the relative impact of risk groups and related risk factors on project performance. Moreover, the CFPR were used to analyze the probability of occurrence and evaluate the level of risk for the overall project. Taylan et al. [19] employed the integration of fuzzy TOPSIS and fuzzy AHP methodology, which is called a hybrid application. They used hybrid fuzzy TOPSIS and fuzzy AHP model for assessing the whole risks of construction projects, which are vague, imprecise and uncertain. The fuzzy TOPSIS method was used for group decision making, and fuzzy TOPSIS was applied to assess the weight of fuzzy linguistic variables for all the construction project risk factors.

Aydogan and Koksal [87] prioritized the risks of international construction projects using the analytical network process (ANP). The ANP was selected because they recognized it was the most appropriate tool in constructing the framework of international construction risk factors and analyzing the priorities of these risk factors on partner selection because it allowed interdependent relationships in a multi-criteria decision model. Chemweno et al. [93] proposed a new methodology for choosing 
the suitable risk assessment method for the maintenance decision-making field. They integrated the analytical network process into the methodology for prioritizing and accounting for the opinions and judgments of industrial and academic experts. Fazli and Mavi [37] proposed a decision network framework for risk assessment in crude oil supply chains that incorporated DEMATEL and ANP. DEMATEL analyzed the interdependency among the risk factors and ANP ranked the risk factors and evaluated the importance of each risk factor.

The recent studies carried out on oil and gas projects do not cover all the keywords of this study such as risk assessment, oil and gas, construction projects within a unit study. For example, the study by Wood [94] focused only on understanding of project performance for oil and gas industry especially for those projects associated with major time-cost-quality uncertainties. This study did not consider identification of risks within the projects and their effects on project objectives such as time-cost-quality. A study by Meidell and Kaarbøe [95] about enterprise risk management (ERM) within an oil and gas company setting, focused on the influence of ERM on decision making in an organization. In that study, the risks associated with construction projects had not been considered. Also, the other studies that have concentrated on OGC projects, such as that by Salazar-Aramayo et al. [96], have not introduced risks or proposed risk assessment methodology to evaluate the overall risks in OGC projects.

According to the existing literature review and to the authors' best knowledge, despite the numerous studies related to risk assessment with the application of Multi-Criteria Decision Making (MCDM) techniques such as fuzzy AHP, fuzzy TOPSIS and fuzzy ANP, a synthesized risk assessment using DEMATEL-ANP has not yet been established in construction projects. While a few studies have been carried out in the field of construction projects with the same methods, those studies were not within the scope of risk assessment. Therefore, the aim of this study was to use a hybrid tool process while incorporating both the DEMATEL and ANP techniques to achieve a novel risk assessment methodology in the area of construction projects. DEMATEL was applied to expose the relationship between the dimensions and variables as well as to discover the interdependency and feedback between them. In this study, dimension was source of risks (risk group) and variables were risk factors. Conversely, ANP was used to determine the dependency and feedback between the variables in addition to deciding the weight of the dimension and variables.

\subsection{DEMATEL}

The DEMATEL method was created by the Geneva Research Center based on expert knowledge to analyze various factors that affect a system and expose both strength and influence among the factors in addition to converting them into a structural model [97]. This is crucial as it is important and helpful to understand better and solve the cause-and-effect relationship between the factors [38,98]. According to Uygun et al. [39], the DEMATEL concept is adapted in different academic fields, and it has been proven as an effective tool to solve difficult and complicated problems.

The six procedures that are involved in the DEMATEL methodology are described as the following.

Step 1: Calculating the average direct-relation matrix. Firstly, a number of experts are requested to form pairwise comparisons according to the direct influence between the criteria. An influence scale of 0 (no influence), 1 (low influence), 2 (medium influence), 3 (high influence), and 4 (very high influence) is used for comparison. If there are $\mathrm{K}$ respondent experts with $\mathrm{n}$ factors, the results formed for each expert in direct relation of a $n \times n$ matrix, which donated both $x_{i j}^{k}$ and $i j$, is the influential level of criterion $i$ to criterion $j$. The main diagonal of the matrix is zero because in DEMATEL, the self-influence of criteria is not assessed.

$$
X=\left[\begin{array}{cccc}
0 & x_{12} & \cdots & x_{1 n} \\
x_{21} & 0 & \cdots & x_{2 n} \\
\vdots & \vdots & \ddots & \vdots \\
x_{1 n} & x_{n 2} & \cdots & 0
\end{array}\right]
$$


To incorporate all respondent options to achieve a direct relation matrix of $Z=\left[a_{i j}\right]$, the average of each respondent's scores is calculated using Equation (1).

$$
a_{i j}=\frac{1}{k} \sum_{k=1}^{k} x_{i j}^{k}
$$

Step 2: Normalizing the average matrix. The normalizing of matrix $M$ presents the relative intensities of the direct relations. This can be obtained from Equations (2) and (3).

$$
\begin{gathered}
S=\max _{i} \sum_{j=i}^{n} a i j \\
N=\frac{Z}{S}
\end{gathered}
$$

Step 3: Calculating the total relation matrix. The said matrix shows all the relationships among all factors including both indirect and direct. The total-relation matrix, $T$, can be calculated using Equation (4), where I is the identity matrix.

$$
T=\lim _{k \rightarrow \infty}\left(N+N^{2}+\ldots+N^{k}\right)=N(1-N)^{-1}
$$

Step 4: Computing the levels of influence and effect. Vectors $c$ and $r$ represent the sum of columns and rows of matrix $T$ respectively, which are shown in Equations (5) and (6). Indeed, both $c$ and $r$ indicate the rate of both direct and indirect effect and influence between the elements in a system.

$$
\begin{aligned}
& c_{j}=\sum_{i=1}^{n} t_{i j} \\
& r_{i}=\sum_{j=1}^{n} t_{i j}
\end{aligned}
$$

Step 5: Calculating the influence and relation vectors. The value of $r-c$ defines the power effect vector, which is a vertical vector. A positive value of $r-c$ indicates that the factor is causal, while a negative value signifies that the factor is effect. In contrast to the value of $r-c$, the value of $r+c$ shows that the relation vector is a horizontal vector, in which it indicates the level of importance between each indication with others. A greater level of $r+c$ for any factor represents higher interrelationships with other factors.

Step 6: Obtaining the causal diagram, Network Relation Map (NRM). The causal diagram can be attained by depicting all dataset of the $(r-c, r+c)$, where the vertical axis is $r-c$ and the horizontal axis is $r+c$. The NRM is a proper diagram, which presents a valuable insight for decision making. NRM can be obtained by defining a threshold value based on the opinions of experts. It also constructs a structural relationship between the different influence factors to visualize complex correlation. For the given reason, negligible relationships should be filtered out from the total-relation matrix $T$. However, only relationships that are greater than the defined value should be shown in the graph.

\subsection{Analytic Network Process (ANP)}

The ANP is one of the MCDM techniques that is utilized to overcome a limitation of a hierarchical structure [99,100]. The ANP is an extension of the analytic hierarchy process (AHP) that was developed by Saaty [101] as a useful tool for settling complex decision making problems. Unlike the AHP, which is structured in a unidirectional hierarchical relationship among the criteria in a decision level, the ANP uses a network system between elements in each decision level. Therefore, ANP is an improved version of AHP to resolve problems with dependencies among criteria in a system that is divided 
into different decision clusters with each cluster containing several criteria [101]. In ANP, the network connections between clusters and criteria express dependencies that can be inner or outer dependencies. Dependencies between elements in one cluster are represented as inner dependencies, however, dependencies among criteria in the same cluster and those in a dissimilar cluster are represented as outer dependencies [93]. The ANP model allows a complex relationship between criteria, but it cannot construct a hierarchical structure for decision problems that involve dependencies and interactions of higher-level elements on lower-level elements [37].

Next, the steps related to the ANP method are described. The said technique is comprised of four steps.

Step 1: Conducting the pairwise comparison. This can be done by using pairwise comparison questionnaire between the interactions of the elements. The said questionnaire involves a nine-point scale, which ranges from equal importance to extreme importance. The valid importance of each series of comparison between the elements are determined by experts.

Step 2: Forming the supermatrix. In this second step, the outcomes obtained from the previous step are used to construct an unweighted supermatrix, which includes priorities that are derived from the different pairwise comparisons. A supermatrix can be described in a general form as shown in Equation (7):

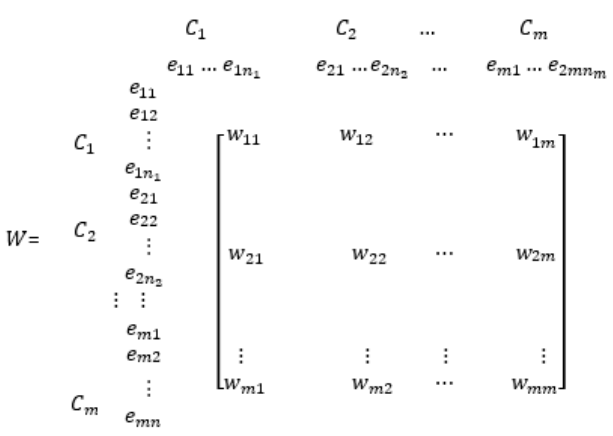

where $c_{m}$ represents the $m$ th cluster [98], $e_{m n}$ indicates the $m$ th element in the $m$ th cluster [102], and $w_{i j}$ is the principle eigenvector of the influence of the elements, which are compared between the $i$ th and $j$ th clusters [37].

Step 3: Attaining the weighted supermatrix. Firstly, the matrix should be normalized by the sum to the unity of each column. This is due to the fact that clusters are usually interdependent in a network while elements in the columns are separated by the number of clusters. Thus, the normalizing method represents that clusters have equal weight. Subsequently, the unweighted supermatrix is multiplied with the corresponding cluster priority to attain the weighted supermatrix.

Step 4: Limiting the supermatrix. In this final step, the weighted supermatrix is raised to sufficiently power $k$ using Equation (8) until it is stable enough to obtain overall priorities or donated ANP weight.

$$
\lim _{k \rightarrow \infty} w^{k}
$$

\section{Empirical Study}

\subsection{Hierarchical Structure of Risk Factors}

According to the literature review in the previous section, the sources of project risk in construction projects have been explored. Common classifications of risk groups, risk factors and risk identification techniques for construction projects are presented in Table 1. The possible risk factors that affect OGC projects were accurately selected, evaluated and classified based on interviews with several experts and the literature review. Several experts verified the context of probable risk factors for OGC projects. Risk factors can be classified into six main groups: financial, policy and political, weather and environment, design and construction, contractual and technical. These risk factors were 
classified based on experts' view points, and according to the Source that affects them. For example, they believed that "design changes in different stages" mostly are related to technical problems. The ultimate hierarchical structure of probable risks for OGC projects is presented in Figure 2. In this section, we evaluate the proposed risk analysis and assessment process based on DEMATEL and ANP for the overall project risk evaluation applied to OGC projects. The simulation results help decision making procedure by prioritizing the important risk factors in OGC, and also aid to mitigate and adopt the consecutive impact of risk factors to the project.

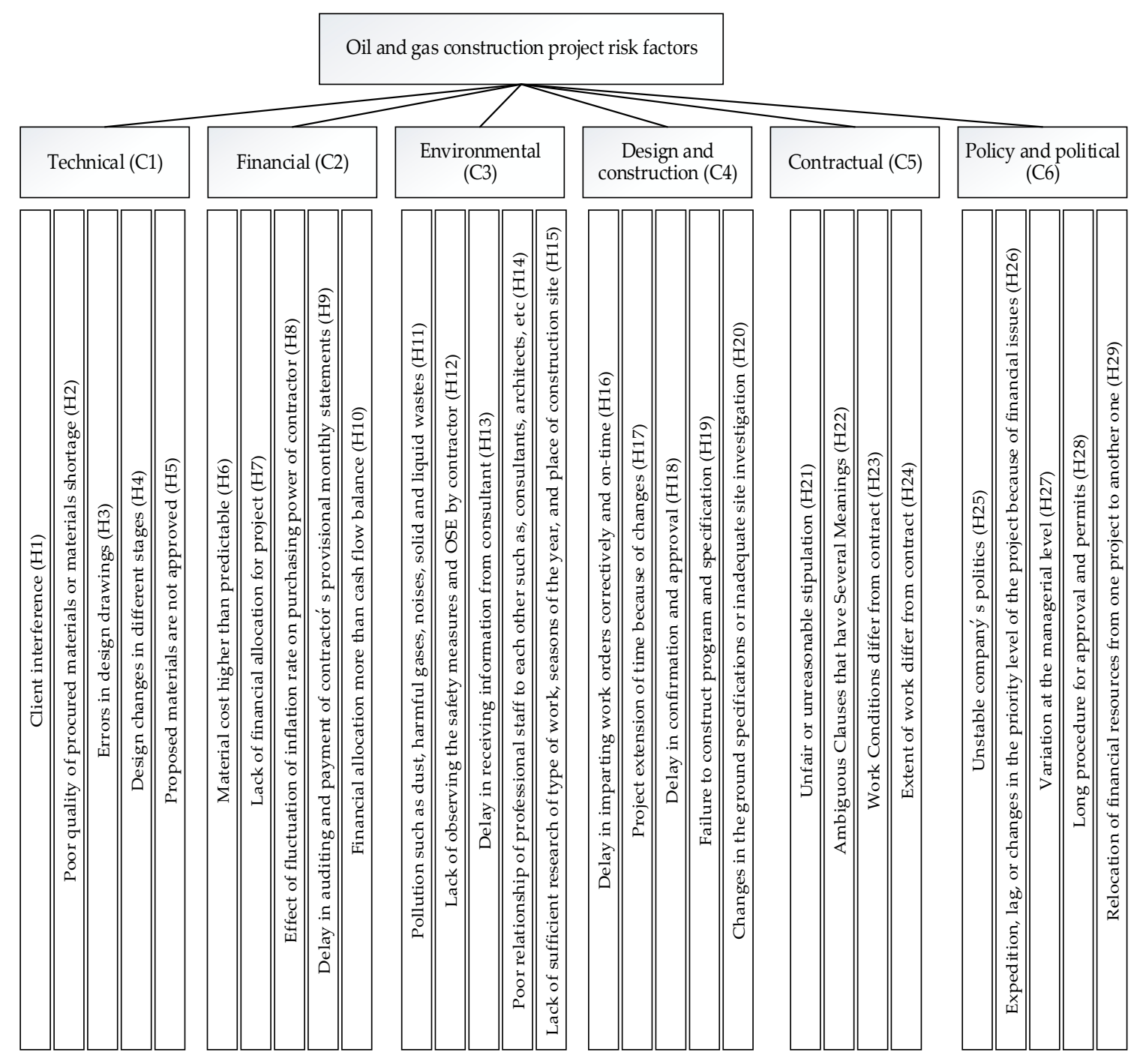

Figure 2. Hierarchical structure of risk factors for OGC projects.

\subsection{Data Collection}

According to Hu et al. [103], the number of questionnaires for DEMATEL techniques should be between three and nine respondents. Also, there is not a general rule for the number of responses necessary in MCDM techniques such as ANP, but it is technically valid that MCDM does not require a large sample. The MCDM techniques such as ANP are not statistically-based [104] decision making approaches. Recently, many studies have applied MCDM techniques such as AHP, ANP and DEMATEL or a combination of these techniques to small sample sizes $[32,98,105,106]$. Thus, a sample size of nine respondents would be adequate for date collection and analysis. A sample of the respondent profiles is presented in Table 2. As seen in Table 2, most of the respondents are in top-level positions and have more than ten years of experience in OGC projects. The questionnaire was used to collect responses 
from experts, which included consultants, project managers, contractors, technicians, and employees attached to planning and programming departments.

Table 2. Profile of experts surveyed in the study.

\begin{tabular}{cccccccccc}
\hline \multicolumn{2}{c}{ Years of Experience in Construction } & \multicolumn{1}{c}{ Job Position } \\
\hline Description & $\begin{array}{c}\text { Under } \\
10 \text { years }\end{array}$ & $\begin{array}{c}\text { Above 10 and } \\
\text { under 20 }\end{array}$ & $\begin{array}{c}\text { Above } \\
20\end{array}$ & Consultant & $\begin{array}{c}\text { Project } \\
\text { manager }\end{array}$ & $\begin{array}{c}\text { Site } \\
\text { manager }\end{array}$ & $\begin{array}{c}\text { Head of } \\
\text { technical } \\
\text { department }\end{array}$ & $\begin{array}{c}\text { Contractor } \\
\text { Head of Programming } \\
\text { and planning } \\
\text { department }\end{array}$ \\
\hline Number & 2 & 3 & 4 & 2 & 2 & 1 & 2 & 1 & 1 \\
\hline Percentage & $22 \%$ & $33 \%$ & $45 \%$ & $22 \%$ & $22 \%$ & $11 \%$ & $22 \%$ & $11 \%$ & $11 \%$ \\
\hline
\end{tabular}

\subsection{DEMATEL Analysis}

In the first step, nine experts in the field of OGC projects were asked to indicate the level of direct influence between criteria that are defined in Section 4.1, using a range of 0 to 4 . To analyze the interrelationships among the six dimensions (risk groups), DEMATEL is used to calculate the causal impact of each risk management dimension in an OGC project. First, a direct-relation matrix is developed using pairwise comparisons of individual expert's opinions in terms of direction and influence between factors. The average direct relation matrix is developed using Equation (1) to combine all ratings of the experts. Then, the total relation matrix, which represents the total influence between factors, is calculated based on the normalized direct influence matrix using Equations (2)-(4), as shown in Table 3.

Table 3. Total relation matrix based on DEMATEL survey of experts in OGC.

\begin{tabular}{|c|c|c|c|c|c|c|}
\hline Dimension & Technical & Financial & Environmental & $\begin{array}{l}\text { Design and } \\
\text { Construction }\end{array}$ & Contractual & $\begin{array}{c}\text { Policy and } \\
\text { Political }\end{array}$ \\
\hline Technical & 1.5279 & 1.7903 & 1.1076 & 1.6530 & 1.6450 & 1.4070 \\
\hline Financial & 1.7883 & 1.6852 & 1.1732 & 1.7056 & 1.7229 & 1.4976 \\
\hline Environmental & 1.5211 & 1.5679 & 0.9069 & 1.4660 & 1.4738 & 1.2480 \\
\hline Design and construction & 1.6108 & 1.6778 & 1.0392 & 1.3642 & 1.5026 & 1.3004 \\
\hline Contractual & 1.5745 & 1.6849 & 1.0289 & 1.5205 & 1.3780 & 1.3424 \\
\hline Policy and political & 1.5424 & 1.6585 & 0.9956 & 1.4612 & 1.5206 & 1.1643 \\
\hline
\end{tabular}

To calculate the influence vector and relation vector, Equations (5) and (6) are employed. For the six risk groups, the influence vector and relation vector are shown in Table 4, represented by $(r-c)$ and $(r+c)$, respectively. As seen in Table 4, environmental and policy and political factors have positive values of $r-c$. Therefore, these factors affect other factors, while design and contractual factors are the most influenced by all the other factors. Furthermore, the financial and technical factors have major interactions with other factors because they have highest level of $r+c$ and environmental and policy factors have the least interaction with other factors.

Table 4. Total influence and relation for each dimension, based on DEMATEL survey of experts in OGC.

\begin{tabular}{cccccc}
\hline Dimension & Code & $\mathbf{r}$ & $\boldsymbol{c}$ & $\boldsymbol{r}+\boldsymbol{c}$ & $\boldsymbol{r}-\boldsymbol{c}$ \\
\hline Technical & $\mathrm{C} 1$ & 9.1307 & 7.6029 & 18.6957 & -0.4343 \\
Financial & $\mathrm{C} 2$ & 9.5729 & 7.7846 & 19.6374 & -0.4917 \\
Environmental & $\mathrm{C} 3$ & 8.1837 & 6.6625 & 14.4350 & 1.9323 \\
Design and construction & C4 & 8.4949 & 6.8842 & 17.6654 & -0.6755 \\
Contractual & C5 & 8.5291 & 6.9546 & 17.7721 & -0.7138 \\
Policy and political & C6 & 8.3426 & 6.8001 & 16.3023 & 0.3828 \\
\hline
\end{tabular}

In the last step, the NRM and causal diagram are obtained from Tables 3 and 4 . In order to construct an appropriate NRM, it is necessary that decision-makers set a threshold value for the 
influence level. In this regard, the threshold value of 1.10 was set after discussion with experts. Therefore, values greater than the threshold value of 1.10 in Table 3 are compiled and included in the NRM, as shown in Figure 3. Based on this map, the direct and indirect influences can be represented. It should be noted that based on the opinions of experts, only the most influenced relations are selected from the total relation matrix. The environmental risks have less of a relation with other factors. Also, technical and financial risk factors have high interrelationships with other factors. Furthermore, all risk factors except the environmental risk factor are themselves affected indirectly by other risk groups because these risks have no direct effect on themselves.

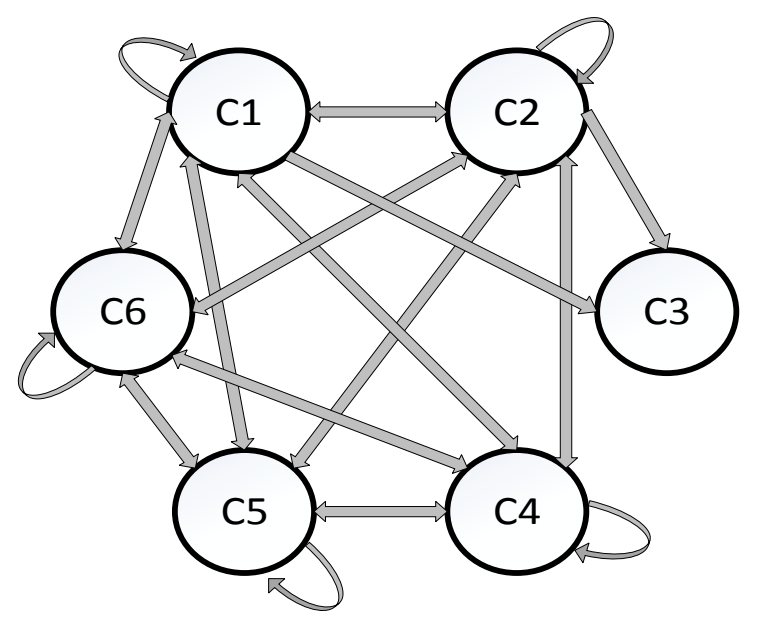

Figure 3. Network Relation Model (NRM) depicting influences of various risk factors.

A causal diagram can be plotted (Figure 4) by using dataset $(r+c)$ and $(r-c)$, which are given in Table 4. As shown in Figure 4, all risk factors were divided into both cause and effect clusters. The effect cluster was comprised of $\mathrm{C} 1, \mathrm{C} 2, \mathrm{C} 4$, and $\mathrm{C} 5$ with negative values of $(r-c)$, whereas the cause cluster included C 3 and $\mathrm{C} 6$ with $(r-c)$ positive values. It can also be seen that $\mathrm{C} 3$ was the highest causal factor while both $\mathrm{C} 4$ and $\mathrm{C} 5$ were the highest effect factors. In addition, both $\mathrm{C} 1$ and $\mathrm{C} 2$ were identified as the most important factors as they demonstrated high levels of interrelationship with other factors.

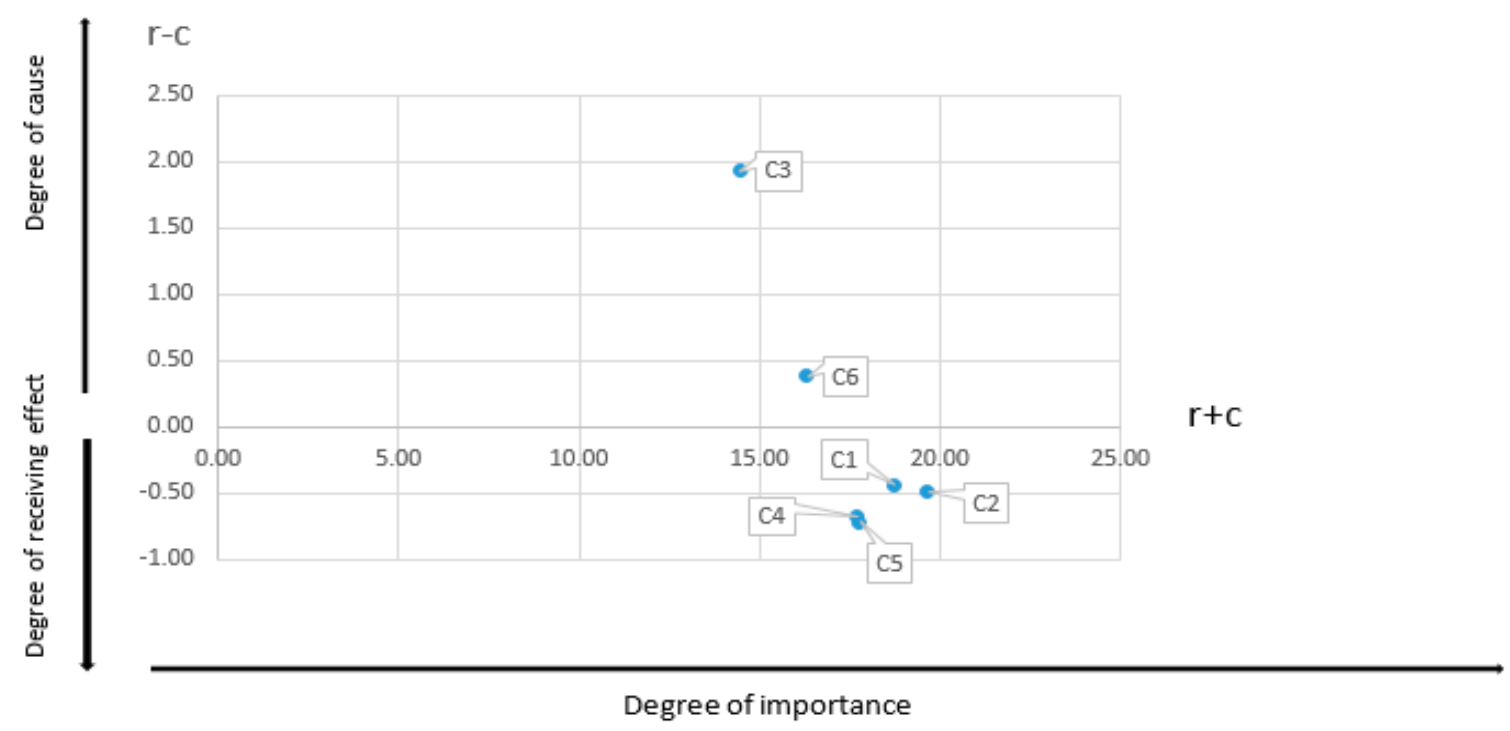

Figure 4. Causal diagram for dimensions. 


\subsection{ANP Analysis}

In this section, after determining the interdependency among criteria using DEMATEL, the ANP technique is applied to attain the final weight of the six risk groups and their risk factors. A pairwise comparison question with Saaty's nine-point scale was conducted and distributed to nine experts who had been involved with OGC projects in Iran. The questionnaire was conducted based on the ANP model and a relation network structure among the criteria. In the survey, they were asked questions such as: "In an OGC project, how much more important is "financial risk" compared with "technical risk"?"

The first step in the analysis was that the ANP model was constructed based on the relationship structure that was developed using DEMATEL, as shown in Figure 5. As can be seen, each dimension has a direct relation with its corresponding subset. Also, the loops indicate the internal relation of each group, which means risk affects itself indirectly through other risk groups. To construct this decision model and also to solve the supermatrix, this study used Super Decisions software (available at: http:/ / www.superdecisions.com/). This is a professional software that is easy to use for constructing decision models. This software helped to build pairwise comparison matrices, compute the results for defining the supermatrix and find the limited supermatrix and weight of each factor. Furthermore, during the whole computing process, the consistency was tested by the software. The consistency ratio (C.R) is a measure of consistency that confirms that the original ratings of the experts have been maintained. It is recommended that the consistency ratio should be less than or equal to 0.10 .

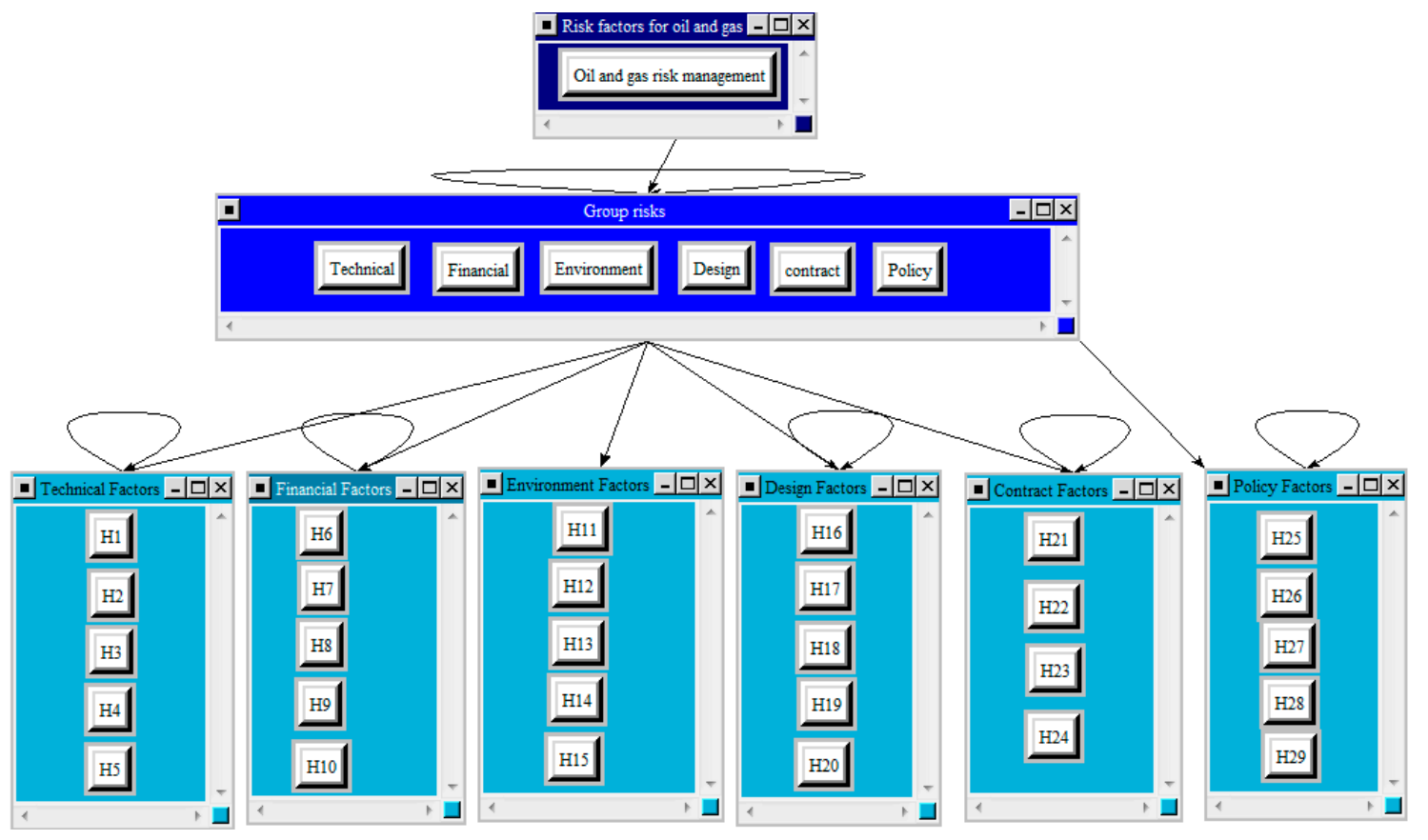

Figure 5. The ANP Decision network model.

Based on the ANP methodology, in the first step, a pairwise comparison matrix was conducted for the dimensions (technical, financial, environmental, policy and political, and design and construction) as shown in Table 5. In the second step, the pairwise comparisons were performed for all factors in each dimension. These comparison matrices should be formed based on the model and relationships between dimensions and among factors in each dimension.

The limited supermatrix is the final step, which should be calculated after the unweighted and weighted supermatrix. The limited supermatrices are presented in Table 6 . The final weight of each factor for the corresponding dimension is calculated in the limited supermatrix. 
Table 5. Dimension comparison with respect to overall goal.

\begin{tabular}{|c|c|c|c|c|c|c|c|}
\hline With Respect to the Goal & Technical & Financial & Environmental & $\begin{array}{l}\text { Design and } \\
\text { Construction }\end{array}$ & Contractual & $\begin{array}{l}\text { Policy and } \\
\text { Political }\end{array}$ & $\begin{array}{l}\text { Weight } \\
\text { Factor }\end{array}$ \\
\hline Technical & 1 & & & & & & 0.26 \\
\hline Financial & 1.4 & 1 & & & & & 0.29 \\
\hline Environmental & 0.2 & 0.2 & 1 & & & & 0.11 \\
\hline Design and construction & 0.6 & 0.7 & 0.8 & 1 & & & 0.15 \\
\hline Contractual & 0.4 & 0.4 & 0.6 & 0.6 & 1 & & 0.09 \\
\hline Policy and political & 0.7 & 0.3 & 0.8 & 0.4 & 1.5 & 1 & 0.10 \\
\hline \multicolumn{8}{|c|}{$\mathrm{C} R=0.04758$ (acceptable value to be less than 0.1 ) } \\
\hline
\end{tabular}

Table 6. The Limited Supermatrix.

\begin{tabular}{|c|c|c|c|c|c|c|c|c|c|c|c|c|c|c|c|}
\hline & & Techni & & & & & & & & & & & & & \\
\hline & H1 & $\mathrm{H} 2 \quad \mathrm{~F}$ & $\mathrm{H} 3 \mathrm{H} 4$ & $\mathrm{H} 5$ & & & & & & & & & & & \\
\hline $\mathrm{H} 1$ & & & 0.190 .19 & 0.19 & & & & & & & & & & & \\
\hline $\mathrm{H} 2$ & 0.26 & 0.260 & 0.260 .26 & 0.26 & & & & & & & & & & & \\
\hline $\mathrm{H} 3$ & 0.29 & 0.290 & 0.290 .29 & 0.29 & & Financial & & & & & & & & & \\
\hline $\mathrm{H} 4$ & 0.14 & $=0.140$ & $0.14 \quad 0.14$ & $=0.14$ & & $\begin{array}{lll}\mathrm{H} 7 & \mathrm{H} 8 & \mathrm{H} 9\end{array}$ & & & & & & & & & \\
\hline H5 & & & & $\begin{array}{l}0.11 \\
\mathrm{H} 6\end{array}$ & 0.12 & $\begin{array}{lll}0.12 & 0.12 & 0.12\end{array}$ & 0.12 & & & & & & & & \\
\hline & & & & H7 & 0.31 & $\begin{array}{lll}0.31 & 0.31 & 0.31\end{array}$ & 0.31 & & & & & & & & \\
\hline & & & & $\mathrm{H} 8$ & & $\begin{array}{llll}0.18 & 0.18 & 0.18 & \end{array}$ & & & Environment & & & & & & \\
\hline & & & & H9 & & $\begin{array}{lll}0.24 & 0.24 & 0.24\end{array}$ & 0.24 & & & & & & & & \\
\hline & & & & $\mathrm{H} 10$ & 0.16 & $\begin{array}{lll}0.16 & 0.16 & 0.16\end{array}$ & 0.16 & H11 & H12 H13 H14 & H15 & & & & & \\
\hline & & & & & & & H11 & 0.18 & $\begin{array}{llll}0.18 & 0.18 & 0.18 & \end{array}$ & 0.18 & & & & & \\
\hline & & & & & & & H12 & 0.20 & $\begin{array}{lll}0.20 & 0.20 & 0.20\end{array}$ & 0.20 & & & & & \\
\hline & & & & & & & H13 & 0.21 & $\begin{array}{lll}0.21 & 0.21 & 0.21\end{array}$ & & Desion & & & & \\
\hline & & & & & & & H14 & 0.21 & $\begin{array}{lll}0.21 & 0.21 & 0.21\end{array}$ & & & & & & \\
\hline & & & & & & & H15 & 0.20 & $\begin{array}{lll}0.20 & 0.20 & 0.20\end{array}$ & 0.20 & H16 H17 H18 H1s & $19 \mathrm{H} 20$ & & & \\
\hline & & & & & & & & & & H16 & $\begin{array}{llll}0.21 & 0.21 & 0.21 & 0.21\end{array}$ & 210.21 & & & \\
\hline & & & & & & & & & & H17 & $\begin{array}{llll}0.21 & 0.21 & 0.21 & 0.21\end{array}$ & 210.21 & & & \\
\hline & & & & & & & & & & H18 & $\begin{array}{llll}0.15 & 0.15 & 0.15 & 0.15\end{array}$ & 150.15 & Contractual & & \\
\hline & & & & & & & & & & H19 & $\begin{array}{llll}0.17 & 0.17 & 0.17 & 0.17\end{array}$ & 170.17 & $\mathrm{H} 21 \mathrm{H} 2 \mathrm{H}_{23}$ & $\mathrm{H} 24$ & \\
\hline & & & & & & & & & & $\mathrm{H} 20$ & $\begin{array}{llll}0.25 & 0.25 & 0.25 & 0.25\end{array}$ & $\begin{array}{rl}25 & 0.25 \\
& \text { H21 }\end{array}$ & $\begin{array}{lll}\mathrm{H} 21 & \mathrm{H} 22 & \mathrm{H} 23 \\
0.21 & 0.21 & 0.21\end{array}$ & 0.21 & \\
\hline & & & & & & & & & & & & H22 & $\begin{array}{lll}0.44 & 0.44 & 0.44\end{array}$ & & Policy and Political \\
\hline & & & & & & & & & & & & $\mathrm{H} 23$ & $\begin{array}{lll}0.18 & 0.18 & 0.18\end{array}$ & & Foricy and rolitical \\
\hline & & & & & & & & & & & & $\mathrm{H} 24$ & $\begin{array}{lll}0.17 & 0.17 & 0.17\end{array}$ & 0.17 & 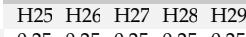 \\
\hline & & & & & & & & & & & & & & $\mathrm{H} 25$ & 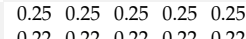 \\
\hline & & & & & & & & & & & & & & & $\begin{array}{lllll}0.22 & 0.22 & 0.22 & 0.22 & 0.22\end{array}$ \\
\hline & & & & & & & & & & & & & & & 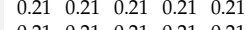 \\
\hline & & & & & & & & & & & & & & $\begin{array}{l}\text { ח2O } \\
\mathrm{H} 29\end{array}$ & 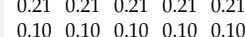 \\
\hline
\end{tabular}

\section{Discussion}

This study proposed a hybrid analysis Multi-Criteria Decision Making (MCDM) model using the DEMATEL and ANP methods to assess crucial risk factors that are related to OGC projects in Iran. The objective of this study was to determine the key risk groups and risk factors and propose a risk assessment framework to evaluate the overall risks in OGC projects. Based on past studies, 29 important risk factors related to construction risks were identified and classified into six main groups and verified by experts.

DEMATEL was employed to determine the interdependencies among risk dimensions, and the results are depicted in Tables 3 and 4. Based on these results, a network relation map (NRM) and causal diagram were constructed, which are presented in Figures 3 and 4. The NRM is a useful visual structure model that reveals the relationship between the different influence factors. This a diagram that aids managers in the decision making process. For example, to respond to financial risk groups without considering technical risk groups, a desirable result cannot be achieved because of the high influence degree between them. In addition, the effect and intensity among factors can be illustrated using a causal diagram. According to the results obtained in Table 4 and Figure 4, "financial" and "technical" dimensions are the most important risk groups because they have the highest rate of $r+c$ and high interrelationship with other risk groups. Furthermore, this diagram indicated that the environmental dimension with the highest value of $r-c$ mostly affects other dimensions. In fact, the Environmental risk dimension has a critical role in success of risk management within OGC projects. This means that desirable goals through other dimensions will not necessarily be achieved without due consideration of environmental risk factors. On the other hand, design and contractual dimensions 
both are the most affected by all the other factors. Therefore, managers should consider all others factors when responding to these risk factors.

According to the ANP result, which is presented in Table 5, we can see the weights of the six important group risks (C1, C2, C3, C4, C5 and C6) in OGC projects are 0.26, 0.29, 0.11, 0.15, 0.09 and 0.10 , respectively. These results imply that the financial and technical risks are the most important risk groups and contractual risks are the least important. The results indicate that "lack of financial allocation for a project" and "delay in auditing and payment of contractor's provisional monthly statements" are the most important factors in the financial risk group. Thus, based on the viewpoints of experts, a delay in payment can be a high level of risk in OGC projects for situations that have a direct effect on project objectives. Also, in the technical risk group, "errors in design drawings" and "poor quality of procured materials or materials shortage" are the most important factors. Therefore, a high level of supervision on design drawings before starting the project is necessary. Furthermore, these results prove that in these types of projects, a professional team with knowledge of quality control is necessary to avoid any error during construction. In addition, in the design and construction group risk, based on expert judgment, "changes in the ground specifications or inadequate site investigation" is the most important factor. To avoid this risk, a thorough investigation of a site specification before starting construction is necessary. Furthermore, for the environmental dimension, "lack of observing the safety measures and OSE by a contractor" and "poor relationship of professional staff to each other such as, consultants, architects, etc." are the most important risk factors that should be considered. This shows that more attention should be given to cooperation between members in these projects such as contractors, client and staff to prevent these risk factors. In the "policy and political dimension", three risk factors of "unstable company politics", "expedition, lag, or changes in the priority level of the project because of financial issues," and "variations at the managerial level" have the same weight and are more important than the other two factors. In the "contractual risk groups", experts agree that "ambiguous clauses that have several meanings" is the most important risk factor. This shows that companies that are involved in oil and gas projects should give more attention to the clauses in contracts with ambiguous language to avoid subsequent risks that correspond to this factor.

As seen in Table 6, the most important risk factors related to OGC projects in Iran are: "lack of financial allocation for the project", "errors in design drawings", "delay in auditing and payment of contractor's provisional monthly statements," and "poor quality of procured materials or materials shortage". Therefore, based on experts' viewpoints these risks factors have critical roles to play for a successful risk management implementation within OGC projects. These highly important risk factors are related to "financial" and "technical" dimensions, which are the most important group risks. Hence, it is recommended that decision makers, policy makers, managers should pay attention more to these risk factors due to their direct effects on project success.

The results of this study show that the DEMATEL-ANP approach can provide two effective types of information to the managers: causal relationships between criteria and the weight of risk factors. The weight of risk factors presents the critical risk factors that should be attended and responded to within OGC projects. The causal relationships present an overview to managers on how these risk factors should be treated that have effective influence. The proposed DEMATEL-ANP method can help to boost the process of risk assessment and improve the efficiency simultaneously. The ANP weight helps to prioritize those risk factors that should be improved so that the managers can concentrate on responding to the critical risks. DEMATEL implies that responding to the critical risks efficiently, requires that their "cause" factors should be treated concurrently in order to ensure achievement of the project objectives.

Furthermore, this result can present a suitable overview of the OGC project to a manager. This methodology can help risk evaluation during project selection and group decision making of project management experts involved in the OGC industry. Furthermore, this study can serve as a guide for risk assessment policy planning to government planners and stockholders to help ensure a sustainable energy supply chain. The proposed DEMATEL and ANP model is a useful process to evaluate and 
assess identified risks. Both tools were based on fundamental theory, which promotes the process of evaluating perceived risks. The constructed model, which was developed by the two said tools, would be able to help visualize the complex relationship between risk factors as well as identify the important risk factors that directly affect project objectives. In the future, this method could be adapted to other areas of construction projects.

\section{Conclusions}

Based on the important role of energy in the global economy, it is necessary to investigate significant risks faced by construction companies that are involved in producing and processing oil and gas. This study proposed a multi-criteria decision making model for assessing the risks and formulation of policies in OGC projects by employing a DEMATEL-ANP model. The main risk groups and possible risk factors were extracted from literature and evaluated by experts. The current study attempted to identify both dimension and variables of critical risk factors that can have a major and serious effect on implementing risk management in OGC projects. According the DEMATEL analysis, the interdependencies among risk groups were evaluated to improve the adoption of decision processes in OGC projects. The outcome indicated that from the experts' viewpoint, the "financial" and "technical" dimensions are the most important dimensions because they both have high interrelationships with other dimensions. Based on the cause-effect relationships among the risk dimensions, and according to the experts' judgment, we could conclude that "environmental" risk factors are critical for a successful implementation of risk management within OGC projects due to their effect on other factors. It means improving other risk factors without attending to risk factors that are classified in the environmental dimension cannot have a desirable result. Furthermore, the experts agreed that "contractual" and "design and construction" are the most affected risk factors.

The ANP was applied for weighting and prioritizing critical risk factors in OGC projects. The results show that experts in OGC projects are more concerned about "financial" and "technical", as the weights of these risk groups are significantly higher than other risk dimensions. Furthermore, from the result, it was found that from the experts' viewpoint, "Lack of financial allocation for project", "Errors in design drawings", "Delay in auditing and payment of contractor's provisional monthly statements," and "Poor quality of procured material or material shortage" are the most important risk factors in OGC projects. Therefore, for a successful risk management implementation it is necessary for stakeholders, companies, decision makers, and policy-makers who are active in OGC projects to pay more attention to these risk factors.

The DEMATEL-ANP model has been introduced to assess the risk factors for OGC projects. It has been shown that DEMATEL can be applied to construct interrelations among risk factors in an integrated model and test the strength of interdependencies between risk factors. The DEMATEL outcomes can help managers promote the efficiency of risk assessment of overall risks within OGC projects so that they can respond more easily. Additionally, in the proposed model, it is illustrated how the ANP technique can define the importance of risk factors by weighting and prioritizing critical risk factors in OGC projects. It aids the decision makers to focus on most important risks within OGC projects.

DEMATEL-ANP has been showcased as a method to deliver a new and proper model to facilitate the risk management process, which is to be applied by decision makers in OGC projects for ensuring reliable energy supply planning. This would then lead to proper response towards potential risks during projects as well as avoid or decrease the level of consequences related to the said risks. This is particularly important for managers and members in risk assessment groups whose objectives include developing a model to evaluate risk factors during construction projects. Also, the DEMATEL-ANP model could also be referred or adapted in other parts of construction projects for the purpose of identifying and assessing risks. 
Author Contributions: As the primary author, Rosli Mohamad Zin, Ali Keyvanfar, and Ronald McCaffer were as supervisor during providing this manuscript. M. Salim Ferwati and Mu'azu Mohammed Abdullahi contributed toward structuring and editing the paper, and proofreading the manuscript.

Conflicts of Interest: The authors declare no conflict of interest.

\section{References}

1. Accenture. Developing Strategies for the Effective Delivery of Capital Projects: Accenture Global Survey of the Utilities Industry; Accenture: Dublin, Ireland, 2012.

2. Jayaraman, R.; Colapinto, C.; La Torre, D.; Malik, T. Multi-criteria model for sustainable development using goal programming applied to the United Arab Emirates. Energy Policy 2015, 87, 447-454. [CrossRef]

3. Köne, A.Ç.; Büke, T. An Analytical Network Process (ANP) evaluation of alternative fuels for electricity generation in Turkey. Energy Policy 2007, 35, 5220-5228. [CrossRef]

4. Yusuf, Y.Y.; Gunasekaran, A.; Musa, A.; Dauda, M.; El-Berishy, N.M.; Cang, S. A relational study of supply chain agility, competitiveness and business performance in the oil and gas industry. Int. J. Prod. Econ. 2014, 147, 531-543. [CrossRef]

5. Dehdasht, G.; Rosli Mohamad, Z.; Keyvanfar, A. Risk Classification and Barrier of Implementing Risk Management in OGC Companies. J. Teknol. 2015, 77. [CrossRef]

6. Salas, R. Managing Risks at the Early Phases of Oil and Gas Major Capital Projects. In Proceedings of the SPE E\&P Health, Safety, Security and Environmental Conference-Americas, Denver, CO, USA, 16-18 March 2015; Society of Petroleum Engineers: Richardson, TX, USA, 2015.

7. Van Thuyet, N.; Ogunlana, S.O.; Dey, P.K. Risk management in OGC projects in Vietnam. Int. J. Energy Sect. Manag. 2007, 1, 175-194. [CrossRef]

8. Aven, T.; Vinnem, J.E.; Wiencke, H. A decision framework for risk management, with application to the offshore oil and gas industry. Reliab. Eng. Syst. Saf. 2007, 92, 433-448. [CrossRef]

9. Zhao, X.; Luo, D.; Xia, L. Modelling optimal production rate with contract effects for international oil development projects. Energy 2012, 45, 662-668. [CrossRef]

10. De Maere d'Aertrycke, G.; Ehrenmann, A.; Smeers, Y. Investment with incomplete markets for risk: The need for long-term contracts. Energy Policy 2017, 105, 571-583. [CrossRef]

11. Berends, K. Engineering and construction projects for oil and gas processing facilities: Contracting, uncertainty and the economics of information. Energy Policy 2007, 35, 4260-4270. [CrossRef]

12. Hong, J.; Shen, Q.; Xue, F. A multi-regional structural path analysis of the energy supply chain in China's construction industry. Energy Policy 2016, 92, 56-68. [CrossRef]

13. Bacon, R.W.; Besant-Jones, J.E. Estimating construction costs and schedules: Experience with power generation projects in developing countries. Energy Policy 1998, 26, 317-333. [CrossRef]

14. Sadeghi, M.; Shavvalpour, S. Energy risk management and value at risk modeling. Energy Policy 2006, 34, 3367-3373. [CrossRef]

15. Zou, P.X.; Zhang, G.; Wang, J. Understanding the key risks in construction projects in China. Int. J. Proj. Manag. 2007, 25, 601-614. [CrossRef]

16. Mani, V.; Delgado, C.; Hazen, B.T.; Patel, P. Mitigating Supply Chain Risk via Sustainability Using Big Data Analytics: Evidence from the Manufacturing Supply Chain. Sustainability 2017, 9, 608. [CrossRef]

17. Walewski, J.; Gibson, G. International Project Risk Assessment: Methods, Procedures, and Critical Factors; Report No. 31; Center for Construction Industry Studies, University of Texas at Austin: Austin, TX, USA, 2003.

18. Tserng, H.P.; Yin, S.Y.; Dzeng, R.; Wou, B.; Tsai, M.; Chen, W. A study of ontology-based risk management framework of construction projects through project life cycle. Autom. Constr. 2009, 18, 994-1008. [CrossRef]

19. Taylan, O.; Bafail, A.O.; Abdulaal, R.M.; Kabli, M.R. Construction projects selection and risk assessment by fuzzy AHP and fuzzy TOPSIS methodologies. Appl. Soft Comput. 2014, 17, 105-116. [CrossRef]

20. Rasool, M.; Franck, T.; Denys, B.; Halidou, N. Methodology and tools for risk evaluation in construction projects using Risk Breakdown Structure. Eur. J. Environ. Civ. Eng. 2012, 16, s78-s98. [CrossRef]

21. Wang, S.Q.; Dulaimi, M.F.; Aguria, M.Y. Risk management framework for construction projects in developing countries. Constr. Manag. Econ. 2004, 22, 237-252. [CrossRef]

22. Hwang, B.-G.; Zhao, X.; Toh, L.P. Risk management in small construction projects in Singapore: Status, barriers and impact. Int. J. Proj. Manag. 2014, 32, 116-124. [CrossRef] 
23. Taillandier, F.; Taillandier, P.; Tepeli, E.; Breysse, D.; Mehdizadeh, R.; Khartabil, F. A multi-agent model to manage risks in construction project (SMACC). Autom. Constr. 2015, 58, 1-18. [CrossRef]

24. Latham, M., Sr. Constructing the Team: Final Report of the Government/Industry Review of Procurement and Contractual Arrangements in the UK Construction Industry; HMSO: London, UK, 1994.

25. Suddle, S. The risk management of third parties during construction in multifunctional urban locations. Risk Anal. 2009, 29, 1024-1040. [CrossRef] [PubMed]

26. Smith, G.R.; Bohn, C.M. Small to medium contractor contingency and assumption of risk. J. Constr. Eng. Manag. 1999, 125, 101-108. [CrossRef]

27. Majid, M.A.; McCaffer, R. Factors of non-excusable delays that influence contractors' performance. J. Manag. Eng. 1998, 14, 42-49. [CrossRef]

28. Laryea, S. Risk pricing practices in finance, insurance and construction. In Proceedings of the Construction and Building Research Conference of the Royal Institution of Chartered Surveyors (COBRA 2008), Dublin, Ireland, 4-5 September 2008.

29. Taroun, A. Towards a better modelling and assessment of construction risk: Insights from a literature review. Int. J. Proj. Manag. 2014, 32, 101-115. [CrossRef]

30. Zeng, J.; An, M.; Smith, N.J. Application of a fuzzy based decision making methodology to construction project risk assessment. Int. J. Proj. Manag. 2007, 25, 589-600. [CrossRef]

31. Ebrat, M.; Ghodsi, R. Risk assessment of construction projects using network based adaptive fuzzy system. Int. J. Acad. Res. 2011, 3, 411-417.

32. Kuo, Y.-C.; Lu, S.-T. Using fuzzy multiple criteria decision making approach to enhance risk assessment for metropolitan construction projects. Int. J. Proj. Manag. 2013, 31, 602-614. [CrossRef]

33. Greening, L.A.; Bernow, S. Design of coordinated energy and environmental policies: Use of multi-criteria decision-making. Energy Policy 2004, 32, 721-735. [CrossRef]

34. Nieto-Morote, A.; Ruz-Vila, F. A fuzzy approach to construction project risk assessment. Int. J. Proj. Manag. 2011, 29, 220-231. [CrossRef]

35. El-Shehaby, M.; Nosair, I.; Sanad, A.E.-M. Risk assessment and analysis for the construction of off shore oil \& gas projects. Int. J. Sci. Res. Educ. 2014. Available online: http://ijsae.in/ijsaeems/index.php/ijsae/article/ view / 88 (accessed on 11 August 2017).

36. Mubin, S.; Mannan, A. Innovative Approach to Risk Analysis and Management of Oil and Gas Sector EPC Contracts from a Contractor's Perspective. J. Bus. Econ. 2013, 5, 149.

37. Fazli, S.; Mavi, R.K.; Vosooghidizaji, M. Crude oil supply chain risk management with DEMATEL-ANP. Oper. Res. 2015, 15, 453-480. [CrossRef]

38. Chou, Y.-C.; Yang, C.-H.; Lu, C.-H.; Dang, V.T.; Yang, P.-A. Building Criteria for Evaluating Green Project Management: An Integrated Approach of DEMATEL and ANP. Sustainability 2017, 9, 740. [CrossRef]

39. Uygun, Ö.; Kaçamak, H.; Kahraman, Ü.A. An integrated DEMATEL and Fuzzy ANP techniques for evaluation and selection of outsourcing provider for a telecommunication company. Comput. Ind. Eng. 2015, 86, 137-146. [CrossRef]

40. Haghnevis, M.; Sajedi, H. A model for assessment of project management risk models. In Proceedings of the 4th International Management Conference, Tehran, Iran, 20-21 December 2006.

41. Gilbert, A.; Sovacool, B.K.; Johnstone, P.; Stirling, A. Cost overruns and financial risk in the construction of nuclear power reactors: A critical appraisal. Energy Policy 2017, 102, 644-649. [CrossRef]

42. Barber, R.B. Understanding internally generated risks in projects. Int. J. Proj. Manag. 2005, 23, 584-590. [CrossRef]

43. Ling, F.Y.Y.; Hoi, L. Risks faced by Singapore firms when undertaking construction projects in India. Int. J. Proj. Manag. 2006, 24, 261-270. [CrossRef]

44. Adams, F.K. Risk perception and Bayesian analysis of international construction contract risks: The case of payment delays in a developing economy. Int. J. Proj. Manag. 2008, 26, 138-148. [CrossRef]

45. Baccarini, D.; Archer, R. The risk ranking of projects: A methodology. Int. J. Proj. Manag. 2001, 19, 139-145. [CrossRef]

46. Serpell, A.; Ferrada, X.; Rubio, L.; Arauzo, S. Evaluating risk management practices in construction organizations. Procedia-Soc. Behav. Sci. 2015, 194, 201-210. [CrossRef]

47. Palomo, J.; Rios Insua, D.; Ruggeri, F. Modeling external risks in project management. Risk Anal. 2007, 27, 961-978. [CrossRef] [PubMed] 
48. Uher, T.E.; Toakley, A.R. Risk management in the conceptual phase of a project. Int. J. Proj. Manag. 1999, 17, 161-169. [CrossRef]

49. Chapman, R.J. The controlling influences on effective risk identification and assessment for construction design management. Int. J. Proj. Manag. 2001, 19, 147-160. [CrossRef]

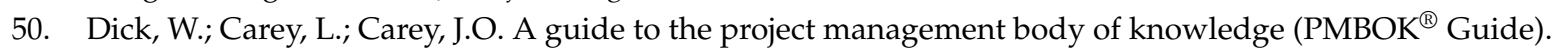
Development 1996, 2, 29-34.

51. Zwikael, O.; Ahn, M. The effectiveness of risk management: An analysis of project risk planning across industries and countries. Risk Anal. 2011, 31, 25-37. [CrossRef] [PubMed]

52. Elkington, P.; Smallman, C. Managing project risks: A case study from the utilities sector. Int. J. Proj. Manag. 2002, 20, 49-57. [CrossRef]

53. Krane, H.P.; Olsson, N.O.; Rolstadås, A. How project manager-project owner interaction can work within and influence project risk management. Proj. Manag. J. 2012, 43, 54-67. [CrossRef]

54. Berkeley, D.; Humphreys, P.; Thomas, R. Project risk action management. Constr. Manag. Econ. 1991, 9, 3-17. [CrossRef]

55. Flanagan, R.; Norman, G. Risk Management and Construction; Wiley-Blackwel: Hoboken, NJ, USA, 1993.

56. Lee, E.; Park, Y.; Shin, J.G. Large engineering project risk management using a Bayesian belief network. Expert Syst. Appl. 2009, 36, 5880-5887. [CrossRef]

57. Project Management Institute (PMI). A Guide to the Project Management Body of Knowledge: PMBOK Guide, 3rd ed.; Project Management Institute Inc.: Newtown Square, PA, USA, 2004.

58. Althaus, C.; Bridgman, P.; Davis, G. The Australian Policy Handbook; Allen \& Unwin: Crows Nest, Australia, 2007.

59. Hubbard, D.W. The Failure of Risk Management: Why It's Broken and How to Fix It; John Wiley \& Sons: Chichester, UK, 2009.

60. Bannerman, P.L. Risk and risk management in software projects: A reassessment. J. Syst. Softw. 2008, 81, 2118-2133. [CrossRef]

61. Project Management Institute (PMI). A Guide to the Project Management Body of Knowledge; Project Management Institute: Newton Square, PA, USA, 2008.

62. El-Sayegh, S.M. Risk assessment and allocation in the UAE construction industry. Int. J. Proj. Manag. 2008, 26, 431-438. [CrossRef]

63. Sukumaran, P.; Bayraktar, M.E.; Hong, T.; Hastak, M. Model for analysis of factors affecting construction schedule in highway work zones. J. Transp. Eng. 2006, 132, 508-517. [CrossRef]

64. Gładysz, B.; Skorupka, D.; Kuchta, D.; Duchaczek, A. Project risk time management—A proposed model and a case study in the construction industry. Procedia Comput. Sci. 2015, 64, 24-31. [CrossRef]

65. Cárdenas, I.C.; Al-Jibouri, S.S.; Halman, J.I.; Tol, F.A. Modeling Risk-Related Knowledge in Tunneling Projects. Risk Anal. 2014, 34, 323-339. [CrossRef] [PubMed]

66. Dziadosz, A.; Rejment, M. Risk Analysis in Construction Project-Chosen Methods. Procedia Eng. 2015, 122, 258-265. [CrossRef]

67. Zayed, T.; Amer, M.; Pan, J. Assessing risk and uncertainty inherent in Chinese highway projects using AHP. Int. J. Proj. Manag. 2008, 26, 408-419. [CrossRef]

68. Baloi, D.; Price, A.D. Modelling global risk factors affecting construction cost performance. Int. J. Proj. Manag. 2003, 21, 261-269. [CrossRef]

69. Klemetti, A. Risk Management in Construction Project Networks; Helsinki University of Technology: Espoo, Finland, 2006.

70. Kartam, N.A.; Kartam, S.A. Risk and its management in the Kuwaiti construction industry: A contractors' perspective. Int. J. Proj. Manag. 2001, 19, 325-335. [CrossRef]

71. Wang, M.-T.; Chou, H.-Y. Risk allocation and risk handling of highway projects in Taiwan. J. Manag. Eng. 2003, 19, 60-68. [CrossRef]

72. Baghdadi, A.; Kishk, M. Saudi Arabian aviation construction projects: Identification of risks and their consequences. Procedia Eng. 2015, 123, 32-40. [CrossRef]

73. Aleshin, A. Risk management of international projects in Russia. Int. J. Proj. Manag. 2001, 19, $207-222$. [CrossRef]

74. Akintoye, A.S.; MacLeod, M.J. Risk analysis and management in construction. Int. J. Proj. Manag. 1997, 15, 31-38. [CrossRef] 
75. Lyons, T.; Skitmore, M. Project risk management in the Queensland engineering construction industry: A survey. Int. J. Proj. Manag. 2004, 22, 51-61. [CrossRef]

76. Perry, J.; Hayes, R. Risk and its management in construction projects. Proc. Inst. Civ. Eng. 1985, 78, 499-521. [CrossRef]

77. Abdou, O.A. Managing construction risks. J. Archit. Eng. 1996, 2, 3-10. [CrossRef]

78. Kalayjian, W.H. Hidden Risks of Construction in the Third World. In Proceedings of the Construction Congress VI: Building Together for a Better Tomorrow in an Increasingly Complex World, Orlando, FL, USA, 20-22 February 2000; pp. 1126-1135.

79. Tah, J.; Carr, V. A proposal for construction project risk assessment using fuzzy logic. Constr. Manag. Econ. 2000, 18, 491-500. [CrossRef]

80. Shen, L.; Wu, G.W.; Ng, C.S. Risk assessment for construction joint ventures in China. J. Constr. Eng. Manag. 2001, 127, 76-81. [CrossRef]

81. Lam, K.C.; Wang, D.; Lee, P.T.; Tsang, Y.T. Modelling risk allocation decision in construction contracts. Int. J. Proj. Manag. 2007, 25, 485-493. [CrossRef]

82. Tang, W.; Qiang, M.; Duffield, C.F.; Young, D.M.; Lu, Y. Risk management in the Chinese construction industry. J. Constr. Eng. Manag. 2007, 133, 944-956. [CrossRef]

83. Karim, N.A.A.; Rahman, I.A.; Memmon, A.H.; Jamil, N.; Azis, A.A.A. Significant risk factors in construction projects: Contractor's perception. In Proceedings of the 2012 IEEE Colloquium on Humanities, Science and Engineering (CHUSER), Kota Kinabalu, Malaysia, 3-4 December 2012; pp. 347-350.

84. Tadayon, M.; Jaafar, M.; Nasri, E. An assessment of risk identification in large construction projects in Iran. J. Constr. Dev. Ctries. 2012, 17, 57-69.

85. El, M.S.B.A.A.; El Nawawy, O.A.M.; Abdel-Alim, A.M. Identification and assessment of risk factors affecting construction projects. HBRC J. 2015. [CrossRef]

86. Mubin, S.; Mubin, G. Risk analysis for construction and operation of gas pipeline projects in Pakistan. Pak. J. Eng. Appl. Sci. 2008, 2, 22-37.

87. Aydogan, G.; Koksal, A. An analysis of international construction risk factors on partner selection by applying ANP approach. In ICCREM 2013: Construction and Operation in the Context of Sustainability, Proceedings of the 2013 International Conference on Construction and Real Estate Management, Karlsruhe, Germany, 10-11 October 2013; American Society of Civil Engineers: Reston, VA, USA; pp. 658-669.

88. Zou, P.X.; Zhang, G.; Wang, J.-Y. Identifying key risks in construction projects: Life cycle and stakeholder perspectives. In Proceedings of the Pacific Rim Real Estate Society Conference, Auckland, New Zealand, 22-25 January 2006.

89. Asgari, S.; Awwad, R.; Kandil, A.; Odeh, I. Impact of considering need for work and risk on performance of construction contractors: An agent-based approach. Autom. Constr. 2016, 65, 9-20. [CrossRef]

90. Zadeh, L.A. Fuzzy sets. Inf. Control 1965, 8, 338-353. [CrossRef]

91. Carr, V.; Tah, J. A fuzzy approach to construction project risk assessment and analysis: Construction project risk management system. Adv. Eng. Softw. 2001, 32, 847-857. [CrossRef]

92. Dikmen, I.; Birgonul, M.T.; Han, S. Using fuzzy risk assessment to rate cost overrun risk in international construction projects. Int. J. Proj. Manag. 2007, 25, 494-505. [CrossRef]

93. Chemweno, P.; Pintelon, L.; Van Horenbeek, A.; Muchiri, P. Development of a risk assessment selection methodology for asset maintenance decision making: An analytic network process (ANP) approach. Int. J. Prod. Econ. 2015, 170, 663-676. [CrossRef]

94. Wood, D.A. Gas and oil project time-cost-quality tradeoff: Integrated stochastic and fuzzy multi-objective optimization applying a memetic, nondominated, sorting algorithm. J. Nat. Gas Sci. Eng. 2017, 45, 143-164. [CrossRef]

95. Meidell, A.; Kaarbøe, K. How the enterprise risk management function influences decision-making in the organization-A field study of a large, global oil and gas company. Br. Account. Rev. 2017, 49, 39-55. [CrossRef]

96. Salazar-Aramayo, J.L.; Rodrigues-da-Silveira, R.; Rodrigues-de-Almeida, M.; de Castro-Dantas, T.N. A conceptual model for project management of exploration and production in the oil and gas industry: The case of a Brazilian company. Int. J. Proj. Manag. 2013, 31, 589-601. [CrossRef]

97. Gabus, A.; Fontela, E. World Problems, an Invitation to Further Thought within the Framework of DEMATEL; Battelle Geneva Research Center: Geneva, Switzerland, 1972. 
98. Supeekit, T.; Somboonwiwat, T.; Kritchanchai, D. DEMATEL-modified ANP to evaluate internal hospital supply chain performance. Comput. Ind. Eng. 2016, 102, 318-330. [CrossRef]

99. Yang, Y.-P.O.; Shieh, H.-M.; Leu, J.-D.; Tzeng, G.-H. A novel hybrid MCDM model combined with DEMATEL and ANP with applications. Int. J. Oper. Res. 2008, 5, 160-168.

100. Zheng, X.; Xu, F.; Feng, L. Analysis of Driving Factors for Extended Producer Responsibility by Using Interpretative Structure Modelling (ISM) and Analytic Network Process (ANP). Sustainability 2017, 9, 540. [CrossRef]

101. Saaty, T.L. Theory and Applications of the Analytic Network Process: Decision Making with Benefits, Opportunities, Costs, and Risks; RWS Publications: Pittsburgh, PA, USA, 2005.

102. Chen, W.-C.; Chang, H.-P.; Lin, K.-M.; Kan, N.-H. An Efficient Model for NPD Performance Evaluation Using DEMATEL and Fuzzy ANP-Applied to the TFT-LCD Touch Panel Industry in Taiwan. Energies 2015, 8, 11973-12003. [CrossRef]

103. Hu, H.-Y.; Lee, Y.-C.; Yen, T.-M.; Tsai, C.-H. Using BPNN and DEMATEL to modify importance-performance analysis model-A study of the computer industry. Expert Syst. Appl. 2009, 36, 9969-9979. [CrossRef]

104. Lam, K.; Zhao, X. An application of quality function deployment to improve the quality of teaching. Int. J. Qual. Reliab. Manag. 1998, 15, 389-413. [CrossRef]

105. Liang, H.; Ren, J.; Gao, Z.; Gao, S.; Luo, X.; Dong, L.; Scipioni, A. Identification of critical success factors for sustainable development of biofuel industry in China based on grey decision-making trial and evaluation laboratory (DEMATEL). J. Clean. Prod. 2016, 131, 500-508. [CrossRef]

106. Yang, J.L.; Tzeng, G.-H. An integrated MCDM technique combined with DEMATEL for a novel cluster-weighted with ANP method. Expert Syst. Appl. 2011, 38, 1417-1424. [CrossRef]

(C) 2017 by the authors. Licensee MDPI, Basel, Switzerland. This article is an open access article distributed under the terms and conditions of the Creative Commons Attribution (CC BY) license (http:/ / creativecommons.org/licenses/by/4.0/). 